Zeszyty Naukowe Szkoły Głównej Gospodarstwa Wiejskiego w Warszawie

Problemy Rolnictwa Światowego tom 19 (XXXIV), zeszyt 1, 2019: 98-109

DOI: 10.22630/PRS.2019.19.1.9

Adam Samborski ${ }^{1}$

Uniwersytet Ekonomiczny w Katowicach

\title{
Finansowanie przedsiębiorstw w krajach Grupy Wyszehradzkiej
}

\section{Financing Enterprises in the Visegrad Group Countries}

\begin{abstract}
Synopsis. W artykule podjęto problematykę finansowania przedsiębiorstw w krajach Grupy Wyszehradzkiej, w latach 1995-2015. W analizach wykorzystano dane źródłowe pochodzące z rachunków narodowych. Na podstawie przeprowadzonych badań zaobserwowano wzrost poziomu samofinansowania w przedsiębiorstwach czeskich, węgierskich, polskich i słowackich. Zauważono także spadek wartości zaciągniętych netto zobowiązań. Wśród przyczyn wskazano na wysoki poziom w sektorze przedsiębiorstw oszczędności brutto oraz spadek wartości nakładów brutto na środki trwałe. Podstawowym źródłem finansowania zewnętrznego były trzy kategorie instrumentów finansowych, a mianowicie: kredyty i pożyczki, udziały kapitałowe, pozostałe kwoty do otrzymania / zapłacenia. We wnioskach podkreślono, iż pomimo spadku poziomu finansowania zewnętrznego nie nastapiły znaczące zmiany w jego strukturze.
\end{abstract}

Słowa kluczowe: przedsiębiorstwo, finansowanie, analiza porównawcza, rachunki narodowe

\begin{abstract}
The article addresses the issue of financing enterprises in the Visegrad Group countries in the years 1995-2015. The analyzes used source data derived from national accounts. On the basis of the conducted research, an increase in the self-financing level was observed in Czech, Hungarian, Polish and Slovak enterprises. A decrease in the value of net liabilities incurred was also noted. Among the reasons, a high level of gross savings in the enterprise sector and a decline in the gross fixed capital formation was indicated. The main source of external funding were three categories of financial instruments, namely loans, equity, other accounts receivable / payable. The conclusions emphasized that despite the decrease in the level of external financing, there were no significant changes in its structure.
\end{abstract}

Key words: enterprise, financing, comparative analysis, national accounts

JEL Classification: D25, F65, G32, M20

\section{Wprowadzenie}

Problematyka finansowania przedsiębiorstw jest niezwykle istotna. Dostępność i różnorodność źródeł finansowania jest warunkiem stabilnego rozwoju poszczególnych przedsiębiorstw, a w efekcie całej gospodarki. Zmiany jakie zachodzą w zewnętrznym środowisku przedsiębiorstw, dotyczące postępujących procesów integracyjnych w obszarze finansów i produkcji, w globalnej przestrzeni, skłaniają do podjęcia badań mających na celu ocenę wpływu tych zmian na sektor przedsiębiorstw. W szczególnej sytuacji znalazły się obecnie przedsiębiorstwa w krajach Grupy Wyszehradzkiej. Z jednej strony struktury tych gospodarek są bardzo zbliżone, a historyczno-gospodarcze uwarunkowania rozwoju podobne. $\mathrm{Z}$ drugiej, gospodarki te są ściśle powiązane, czy to w ujęciu handlowym, czy też

${ }^{1}$ dr hab., prof. UE; Katedra Zarządzania Przedsiębiorstwem, Wydział Zarządzania UE w Katowicach, ul. 1 Maja 50, 40-287 Katowice, e-mail: adam.samborski@ue.katowice.pl; https://orcid.org/0000-0001-7330-5866 
własnościowym, z przedsiębiorstwami wiodących gospodarek Unii Europejskiej (UE). Stopień tych powiazań rośnie wraz ze wstapieniem krajów Grupy Wyszehradzkiej do UE. Warto więc zadać pytanie o zmiany jakie zaszly w ostatnich dwóch dekadach w finansowaniu przedsiębiorstw czeskich, węgierskich, polskich i słowackich. Warto też zastanowić się nad tym, czy zmiany te w podobnym stopniu wywarły wpływ na wzorce finansowania przedsiębiorstw w Czechach, na Wegrzech, w Polsce i Słowacji. Celem opracowania jest jednak nie tylko identyfikacja struktury finansowania przedsiębiorstw $\mathrm{w}$ krajach Grupy Wyszehradzkiej, ale również poznanie uwarunkowań zmian w finansowaniu sektora przedsiębiorstw. Na tym tle istotnym będzie identyfikacja różnic i podobieństw w finansowaniu przedsiębiorstw czeskich, węgierskich, polskich i słowackich.

\section{Źródła danych statystycznych wykorzystanych w badaniu}

Dane wykorzystywane $\mathrm{w}$ analizach zostały pozyskane $\mathrm{z}$ rachunków narodowych, a dokładnie $\mathrm{z}$ rachunku kapitałowego i rachunku finansowego sektora przedsiębiorstw niefinansowych. Rachunki narodowe pozwalają na pełną porównywalność sektora przedsiębiorstw niefinansowych gospodarek krajów zobowiązanych do stosowania Europejskiego Systemu Rachunków (ESA 2010). ESA 2010 jest międzynarodowym standardem metodologicznym i rachunkowym. (Rozporządzenie Parlamentu Europejskiego i Rady (UE) NR 549/2013 z dnia 21 maja 2013 r., s. 33, 1.01). Zgodnie z tym standardem „Sektor przedsiębiorstw niefinansowych (S.11) obejmuje samodzielne jednostki instytucjonalne posiadające osobowość prawną i będące producentami rynkowymi, których podstawową działalnością jest produkcja wyrobów i usług niefinansowych. Do sektora przedsiębiorstw niefinansowych należą także niefinansowe jednostki typu przedsiębiorstwo". (Rozporządzenie Parlamentu Europejskiego i Rady (UE) NR 549/2013 z dnia 21 maja 2013 r., s. 65, 2.45). Rachunek kapitałowy i rachunek finansowy są częścią rachunków akumulacji. Rachunki akumulacji dotyczą przepływów. Na rachunkach akumulacji rejestruje się wszelakie uwarunkowania zmian dotyczących aktywów i zobowiązań jednostek instytucjonalnych, a także zmiany ich wartości netto (Rozporządzenie Parlamentu Europejskiego i Rady (UE) NR 549/2013 z dnia 21 maja 2013 r., s. 259, 8.44).

Rachunek kapitałowy rejestruje nabycie skorygowane o rozdysponowanie aktywów o charakterze niefinansowym, które zostało dokonane przez jednostki instytucjonalne będące rezydentami (tabela 1). Rachunek ten mierzy także zmianę wartości netto (brutto jeżeli uwzględnimy amortyzację środków trwałych), która wynika z oszczędności, jak i transferów kapitałowych (Rozporządzenie Parlamentu Europejskiego i Rady (UE) NR 549/2013 z dnia 21 maja 2013 r., s. 259, 8.46). Rachunek kapitałowy pozwala na określenie zakresu, w jakim różnica pomiędzy nabyciem a rozdysponowaniem aktywów o charakterze niefinansowym była sfinansowana $\mathrm{z}$ oszczędności, a także transferów kapitałowych. Rachunek ten ukazuje albo wierzytelności netto, które odpowiadają kwocie jaka dostępna jest danej jednostce, czy też sektorowi instytucjonalnemu na cele finansowania innych jednostek lub sektorów instytucjonalnych, albo zadłużenie netto, które odpowiada kwocie, jaką dana jednostka, czy też sektor instytucjonalny musi pożyczyć od innych jednostek lub sektorów instytucjonalnych (Rozporządzenie Parlamentu Europejskiego i Rady (UE) NR 549/2013 z dnia 21 maja 2013 r., s. 259, 8.47). Innymi słowy rachunek kapitałowy identyfikuje inwestycje w aktywa niefinansowe i fundusze, z których inwestycje te można 
sfinansować (4.1.). Fundusze pochodzą z oszczędności brutto (źródło wewnętrzne), transferów kapitałowych netto (otrzymane pomniejszone o zapłacone), zadłużenia netto (-) (4.2). Inwestycje w aktywa niefinansowe obejmuja akumulację brutto oraz nabycie pomniejszone o rozdysponowanie aktywów nieprodukowanych (United Nations, 2003, s. $52,4.3)$.

Tabela 1. Schemat rachunku kapitałowego

Table 1. Scheme of the capital account

\begin{tabular}{l|l}
\hline \multicolumn{1}{c|}{ Rozchody } & \multicolumn{1}{c}{ Przychody } \\
\hline $\begin{array}{l}\text { Nakłady brutto na środki trwałe } \\
\text { Przyrost rzeczowych środków obrotowych }\end{array}$ & $\begin{array}{l}\text { Oszczędności brutto } \\
\text { Transfery kapitałowe do otrzymania }(+)\end{array}$ \\
$\begin{array}{l}\text { Nabycie pomniejszone o rozdysponowanie aktywów o } \\
\text { wyjątkowej wartości }\end{array}$ & $\begin{array}{l}\text { Transfery kapitałowe do zapłacenia (-) } \\
\begin{array}{l}\text { Nabycie pomniejszone o rozdysponowanie aktywów } \\
\text { nieprodukowanych } \\
\text { Wierzytelności netto }(+) / \text { zadłużenie netto }(-)\end{array}\end{array}$ \\
\hline
\end{tabular}

Źródło: GUS (Główny Urząd Statystyczny), Zeszyty metodyczne. System rachunków narodowych (SRN). Tom 1. GUS, Warszawa, luty 1996, s. 95; ROZPORZĄDZENIE PARLAMENTU EUROPEJSKIEGO I RADY (UE) NR 549/2013 z dnia 21 maja 2013 r. w sprawie europejskiego systemu rachunków narodowych i regionalnych w Unii Europejskiej, Dziennik Urzędowy Unii Europejskiej L 174/1, s. 597-598.

Rachunek finansowy natomiast rejestruje zmiany, jakie zaszły w aktywach finansowych i zobowiązaniach, które składają się na wierzytelności lub zadłużenie netto (tabela 2). Rejestracja odbywa się według rodzaju instrumentu finansowego (Rozporządzenie Parlamentu Europejskiego i Rady (UE) NR 549/2013 z dnia 21 maja 2013 r., s. 259).

Tabela 2. Schemat rachunku finansowego

Table 2. Scheme of the financial account

\begin{tabular}{l|l}
\hline \multicolumn{1}{c|}{ Zmiana aktywów } & \multicolumn{1}{c}{\begin{tabular}{c}
\multicolumn{1}{c}{ Zmiana zobowiązań i wartości netto } \\
Wierzytelności netto (+)/zadłużenie netto (-)
\end{tabular}} \\
\hline $\begin{array}{l}\text { Nabycie netto aktywów finansowych } \\
\text { Gotówka i depozyty }\end{array}$ & $\begin{array}{l}\text { Zaciagniecie netto zobowiązań } \\
\text { Gotówka i depozyty } \\
\text { Dłużne papiery wartościowe }\end{array}$ \\
$\begin{array}{l}\text { Kredyty i pożyczki } \\
\text { Udziały kapitałowe i udziały w funduszach } \\
\text { inwestycyjnych }\end{array}$ & $\begin{array}{l}\text { Kredyty i pożyczki } \\
\text { Udziały kapitałowe i udziały w funduszach } \\
\text { Systemy ubezpieczeniowe, emerytalno-rentowe i } \\
\text { standaryzowanych gwarancji }\end{array}$ \\
$\begin{array}{l}\text { Instrumenty pochodne i opcje na akcje dla } \\
\text { pracowników } \\
\text { Pozostałe kwoty do otrzymania/zapłacenia }\end{array}$ & $\begin{array}{l}\text { Systemy ubezpieczeniowe, emerytalno-rentowe i } \\
\text { standaryzowanych gwarancji } \\
\text { Instrumenty pochodne i opcje na akcje dla } \\
\text { pracowników }\end{array}$ \\
\hline
\end{tabular}

Źródło: GUS (Główny Urząd Statystyczny), Zeszyty metodyczne. System rachunków narodowych (SRN). Tom 1. GUS, Warszawa, luty 1996, s. 97; ROZPORZADZENIE PARLAMENTU EUROPEJSKIEGO I RADY (UE) NR 549/2013 z dnia 21 maja 2013 r. w sprawie europejskiego systemu rachunków narodowych i regionalnych w Unii Europejskiej, Dziennik Urzędowy Unii Europejskiej L 174/1, s. 598-599. 
Rachunek finansowy identyfikuje więc "inwestycje" w instrumenty finansowe, zadłużenie i formy zadłużenia, a także wyprowadza wierzytelności netto $(+) /$ zadłużenia netto (-) (5.1.). Rachunek finansowy pokazuje więc (a) jak powstaje zadłużenie netto, czy to poprzez zaciaganie zobowiązań, czy też zmniejszanie aktywów finansowych oraz za pomoca jakich instrumentów finansowych, lub (b) jak powstają wierzytelności netto, czy to poprzez nabycie aktywów finansowych, czy też zmniejszenie zobowiązań oraz za pomocą jakich instrumentów (United Nations, 2003, s. 55, 5.3). W rachunku finansowym aktywa finansowe są rejestrowane po lewej stronie, a zobowiązania finansowe po prawej stronie. Wierzytelności netto (+) / zadłużenie netto (-) jest równe sumie aktywów finansowych pomniejszonych o sumę zobowiązań. Wierzytelności netto (+) / zadłużenie netto (-) $\mathrm{z}$ rachunku finansowego muszą być równe kwocie wierzytelności netto $(+)$ / zadłużeniu netto (-) wykazanej w rachunku kapitałowym (United Nations, 2003, s. 92, 11.20). Wierzytelności netto lub zadłużenie netto powinny więc odpowiadać nadwyżce finansowej lub deficytowi finansowemu, które bilansują rachunek kapitałowy. $Z$ tego też względu rachunek finansowy nie ma pozycji bilansującej (Rozporządzenie Parlamentu Europejskiego i Rady (UE) nr 549/2013 z dnia 21 maja 2013 r., s. 259, 8.50).

\section{Saldo wierzytelności i zadłużenia w przedsiębiorstwach niefinansowych}

Jak już wspomniano, saldo wierzytelności i zadłużenia jest pozycją, która bilansuje rachunek kapitałowy. Wierzytelności netto to ilość środków finansowych udostępniana przez dany sektor pozostałym sektorom instytucjonalnym. Zadłużenie netto natomiast to ilość środków finansowych jakie dany sektor instytucjonalny pozyskuje od innych sektorów. W sektorze przedsiębiorstw saldo to przyjmuje $\mathrm{z}$ reguły wartość ujemną. Powstaje więc zadłużenie netto (GUS, 1996, s. 95). Reguła ta znajduje potwierdzenie w przypadku czeskich przedsiębiorstw niefinansowych. W każdym roku okresu 1995-2017 (oprócz 2009 roku - 0,2\% PKB) w czeskim sektorze przedsiębiorstw odnotowano zadłużenie netto, które kształtowało się w przedziale od -0,4\% PKB do -8,5\% PKB (rys. 1). Oznacza to, iż czeskie przedsiębiorstwa niefinansowe zmuszone były pożyczać środki finansowe od innych sektorów instytucjonalnych (GUS, 2000, s. 294). W przypadku natomiast polskiego i węgierskiego sektora przedsiębiorstw wyodrębnić można dwa okresy. $\mathrm{W}$ pierwszym odnotowano zadłużenie netto, w drugim wierzytelności netto. W polskich przedsiębiorstwach niefinansowych zadłużenie netto wystąpiło w latach 1995-2002 oraz w 2007 roku (wartości te kształtowały się od $-0,7 \%$ PKB do -7,4\% PKB), w węgierskich w latach 1995-2008 (przedział od -0,1\% PKB do -7,1\% PKB), oprócz 2002 roku $(2,0 \%$ PKB). W pozostałych latach zanotowano wierzytelności netto, które odpowiadają kwocie dostępnej sektorowi na cele finansowania pozostałych sektorów instytucjonalnych (GUS, 2000, s. 294). W Polsce wierzytelności netto kształtowały się w przedziale od 1,0\% PKB do $7,4 \%$ PKB, na Węgrzech od 3,0\% PKB do 5,9\% PKB. Jeżeli chodzi o słowackie przedsiębiorstwa niefinansowe, to zadłużenie netto wystapiło w okresie 1996-1998, 20012008, a także w 2011 roku (przedział $-0,7 \%$ PKB do $-8,9 \%$ PKB), w pozostałych latach odnotowano wierzytelności netto (przedział od $0,5 \%$ PKB do 7,9\% PKB). 


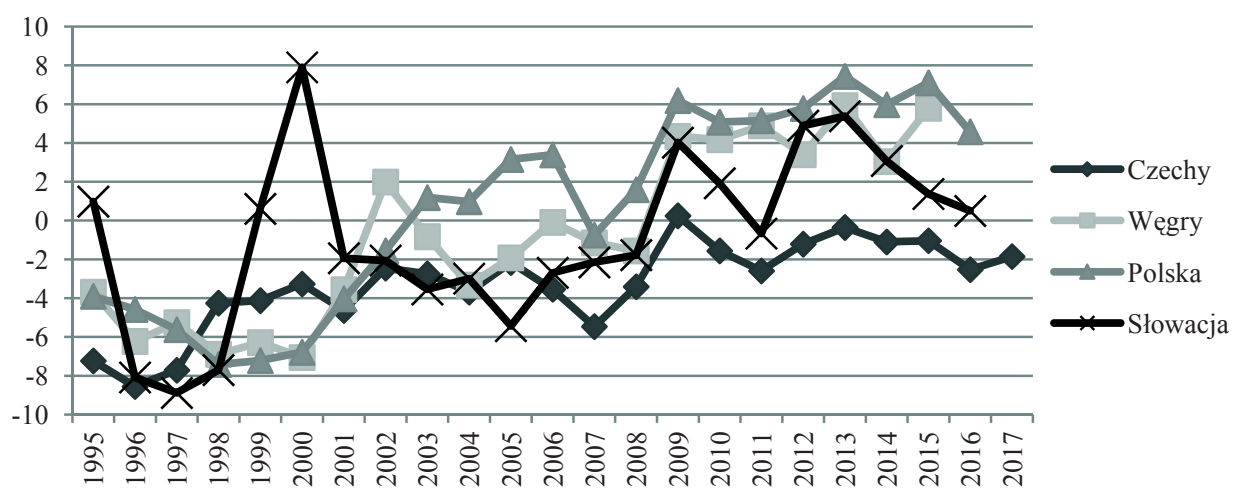

Rys. 1. Saldo wierzytelności i zadłużenia w przedsiębiorstwach niefinansowych w okresie 1995-2017 (\% PKB, transakcje niefinansowe)

Fig. 1. Net lending (+) /net borrowing (-) in non-financial corporations in the period 1995-2017 (\% of GDP, nonfinancial transactions)

Źródło: Eurostat: European sector accounts, https://ec.europa.eu/eurostat/web/sector-accounts/data/database (dostęp: 06.09.2018 r.)

Tabela 3. Saldo wierzytelności i zadłużenia w przedsiębiorstwach niefinansowych w latach 1995-2015 (\% PKB, średnia okresu, transakcje niefinansowe)

Table 3. Net lending (+) /net borrowing (-) in non-financial corporations in the years 1995-2015 (\% of GDP, period average, non-financial transactions)

\begin{tabular}{l|ccccccc}
\hline \multicolumn{1}{c|}{ Kraj } & $1995-1997$ & $1998-2000$ & $2001-2003$ & $2004-2006$ & $2007-2009$ & $2010-2012$ & $2013-2015$ \\
\hline Czechy & $-7,8$ & $-3,9$ & $-3,3$ & $-3,1$ & $-2,9$ & $-1,8$ & $-0,8$ \\
Węgry & $-5,1$ & $-6,7$ & $-0,8$ & $-1,8$ & 0,5 & 4,2 & 4,9 \\
Polska & $-4,7$ & $-7,1$ & $-1,5$ & 2,5 & 2,3 & 5,3 & 6,8 \\
Słowacja & $-5,3$ & 0,3 & $-2,5$ & $-3,7$ & 0,0 & 2,1 & 3,3 \\
\hline
\end{tabular}

Źródło: Eurostat: European sector accounts, https://ec.europa.eu/eurostat/web/sector-accounts/data/database (dostęp: 06.09.2018 r.).

Kluczowe znaczenie dla takiego ukształtowania się salda wierzytelności i zadłużenia w przedsiębiorstwach niefinansowych miały oszczędności brutto, nakłady brutto na środki trwałe i dotacje na inwestycje.

Oszczędności przyjmować mogą zarówno wartość dodatnią jak i ujemną. Przyjęcie przez kategorię tą wartości dodatniej oznacza niewydatkowany dochód przeznaczany na nabycie aktywów lub na spłatę zobowiązań. Jeżeli natomiast oszczędności przyjmują wartość ujemną to część aktywów ulega likwidacji lub część zobowiązań narasta (GUS, 2000, s. 292).

W latach 1995-2015 niewydatkowany dochód w postaci oszczędności brutto utrzymywał się na wysokim poziomie w przedsiębiorstwach niefinansowych w Czechach i Słowacji - odpowiednio w przedziale od $13,6 \%$ PKB do $15 \%$ PKB, oraz $14,5 \%$ PKB do $16,0 \%$ PKB (tabela 4). W przypadku natomiast węgierskiego i polskiego sektora przedsiębiorstw, w analizowanym okresie, poziom oszczędności brutto wzrósł znacząco odpowiednio z 8,4\% PKB do 16,4\% PKB, oraz z 8,1\% PKB do 16,5\% PKB. Trzeba zaznaczyć, iż w latach 1995-2003 dochód do dyspozycji przedsiębiorstw węgierskich 
i polskich kształtował się znacznie poniżej dochodu przedsiębiorstw czeskich i słowackich. Wartości te wyrównały się w kolejnych latach.

Tabela 4. Przedsiębiorstwa niefinansowe - poziom oszczędności brutto, nakładów brutto na środki trwałe, dotacji na inwestycje, samofinansowania (transakcje niefinansowe)

Table 4. Non-financial corporations - level of gross savings, gross fixed capital formation, investment grants, selffinancing (non-financial transactions)

\begin{tabular}{|c|c|c|c|c|c|c|c|}
\hline Kraj & 1995-1997 & $1998-2000$ & $2001-2003$ & 2004-2006 & 2007-2009 & $2010-2012$ & $2013-2015$ \\
\hline & \multicolumn{7}{|c|}{ Oszczędności brutto (\% PKB, średnia roczna) } \\
\hline Czechy & 13,6 & 14,5 & 15,0 & 14,3 & 14,6 & 13,7 & 14,4 \\
\hline Węgry & 8,4 & 10,5 & 12,2 & 13,1 & 13,2 & 15,5 & 16,4 \\
\hline Polska & 8,1 & 8,6 & 8,9 & 13,0 & 13,9 & 15,3 & 16,5 \\
\hline \multirow[t]{2}{*}{ Słowacja } & 14,5 & 15,2 & 15,7 & 14,9 & 15,9 & 15,8 & 16,0 \\
\hline & \multicolumn{7}{|c|}{ Nakłady brutto na środki trwałe (\% PKB, średnia roczna) } \\
\hline Czechy & 22,2 & 19,9 & 18,3 & 17,2 & 17,1 & 16,1 & 16,1 \\
\hline Węgry & 13,4 & 16,0 & 13,7 & 13,5 & 14,0 & 12,5 & 12,9 \\
\hline Polska & 11,7 & 15,2 & 10,6 & 10,0 & 11,4 & 9,6 & 10,2 \\
\hline \multirow[t]{2}{*}{ Słowacja } & 21,2 & 20,9 & 18,3 & 17,4 & 15,6 & 13,8 & 12,5 \\
\hline & \multicolumn{7}{|c|}{ Poziom samofinansowania $=($ Oszczędności brutto/Nakłady brutto na środki trwałe $) * 100$} \\
\hline Czechy & 61,4 & 72,7 & 81,8 & 82,9 & 85,5 & 85,5 & 89,5 \\
\hline Węgry & 62,6 & 65,5 & 89,4 & 96,7 & 93,9 & 123,7 & 127,4 \\
\hline Polska & 69,5 & 56,5 & 84,2 & 129,5 & 121,8 & 159,6 & 162,5 \\
\hline \multirow[t]{2}{*}{ Słowacja } & 68,4 & 72,7 & 85,6 & 86,0 & 102,1 & 114,4 & 128,1 \\
\hline & \multicolumn{7}{|c|}{ Dotacje na inwestycje (\% PKB, średnia roczna) } \\
\hline Czechy & 1,1 & 0,5 & 0,7 & 0,5 & 0,5 & 0,7 & 0,9 \\
\hline Węgry & 1,2 & 1,5 & 1,2 & 0,9 & 1,0 & 1,2 & 1,8 \\
\hline Polska & 0,1 & 0,1 & 0,1 & 0,6 & 0,7 & 0,7 & 1,1 \\
\hline Słowacja & 0,9 & 0,4 & 0,4 & 0,7 & 0,9 & 0,9 & 0,5 \\
\hline
\end{tabular}

Źródło: Eurostat: European sector accounts, https://ec.europa.eu/eurostat/web/sector-accounts/data/database (dostęp: 06.09.2018 r.).

Nakłady brutto na środki trwałe obejmują nabycie aktywów trwałych pomniejszone o ich rozdysponowanie. Sa to m.in. nakłady na rzeczowe środki trwałe oraz nakłady na wartości niematerialne i prawne (GUS, 1997, s. 134). Wartość nakładów brutto na środki trwałe spadła we wszystkich analizowanych krajach. Okres szczytowy odnotowano w końcu lat 90-tych ubiegłego wieku. W czeskim sektorze przedsiębiorstw wartość nakładów brutto na środki trwałe spadła z 22,2\% PKB (średnia z lat 1995-1997) do 16,1\% PKB (średnia $z$ lat 2013-2015), w węgierskim z 16,0\% PKB (średnia $z$ lat 1998-2000) do 12,9\% PKB (średnia z lat 2013-2015), w polskim z 15,2\% PKB (średnia z lat 1998-2000) do $10,2 \%$ PKB (średnia $z$ lat 2013-2015), w słowackim z 21,2\% PKB (średnia $z$ lat 19951997) do $12,5 \%$ PKB (średnia $\mathrm{z}$ lat 2013-2015). Warto $\mathrm{w}$ tym miejscu zaznaczyć, iż $\mathrm{w}$ polskich przedsiębiorstwach niefinansowych wartość nakładów na środki trwałe ukształtowała się na najniższym poziomie wśród analizowanych krajów. 
W efekcie wysokiego poziomu oszczędności brutto (przedsiębiorstwa czeskie i słowackie), czy też wzrostu tego poziomu (przedsiębiorstwa węgierskie i polskie) oraz spadku wartości nakładów brutto na środki trwałe nastapił wzrost poziomu samofinansowania w sektorze przedsiębiorstw analizowanych krajów (tabela 4). W czeskich przedsiębiorstwach niefinansowych z $61,4 \%$ do $89,5 \%$, w węgierskich z $62,6 \%$ do $127,4 \%$, w polskich z $69,5 \%$ do $162,5 \%$, w słowackich z $68,4 \%$ do $128,1 \%$. Wskaźnik samofinansowania mierzy udział oszczędności brutto w nakładach brutto na środki trwałe.

Kolejną kategorią, która miała wpływ na kształtowanie się salda wierzytelności i zadłużenia w przedsiębiorstwach niefinansowych były dotacje na inwestycje. Obejmują one transfery kapitałowe, pieniężne i w naturze, dokonywane na rzecz sektora przedsiębiorstw w celu sfinansowania nabycia środków trwałych (w całości lub części) (GUS, 1997, s. 143). Dotacje na inwestycje we wszystkich latach analizowanego okresu odegrały znaczącą rolę w finansowaniu działalności rozwojowej przedsiębiorstw czeskich, węgierskich i słowackich. W przypadku polskiego sektora przedsiębiorstw do czasu wstapienia Polski do Unii Europejskiej dotacje na inwestycje ukształtowały się na niskim poziomie tj. 0,1\% PKB rocznie. Następnie wzrosły z 0,6\% PKB (średnia z lat 2004-2006) do 1,1\% PKB (średnia z lat 2013-2015).

\section{Źródła finansowania}

W wyniku wzrostu poziomu oszczędności brutto, jak miało to miejsce w przypadku przedsiębiorstw polskich i węgierskich, czy też utrzymywania się oszczędności brutto na wysokim poziomie, co miało miejsce w przedsiębiorstwach czeskich i słowackich oraz spadku nakładów brutto na środki trwałe, spadło też zapotrzebowanie na środki finansowe pozyskiwane $\mathrm{z}$ innych sektorów instytucjonalnych. Wartość zaciągniętych netto zobowiązań w przedsiębiorstwach niefinansowych w latach 1995-2017 pozostaje w trendzie spadkowym we wszystkich analizowanych krajach (rys. 2). Pod koniec lat 90-tych ubiegłego wieku przyrosty zobowiązań finansowych często przekraczały 20\% PKB analizowanych krajów. Po roku 2011 wartości te spadły poniżej 10\% PKB.

Warto więc w tym miejscu zadać sobie pytanie - czy w wyniku spadku zapotrzebowania na zewnętrzne źródła finansowania zmieniła się też jego struktura?

W całym analizowanym okresie podstawowym źródłem finansowania zewnętrznego były trzy kategorie instrumentów finansowych. Są to: kredyty i pożyczki, udziały kapitałowe, pozostałe kwoty do otrzymania / zapłacenia (tabela 5).

W analizowanym okresie przyrosty zobowiązań finansowych z tytułu kredytów i pożyczek w poszczególnych krajach kształtowały się na różnym poziomie. W latach 1995 do 2009 znaczące przyrosty odnotowano w węgierskim sektorze przedsiębiorstw oraz polskim sektorze przedsiębiorstw. W przedsiębiorstwach węgierskich kształtowały się one w przedziale od 6,3\% PKB do 9,7\% PKB, w przedsiębiorstwach polskich od 1,3\% PKB do 4,7\% PKB. Po roku 2009 wartości te znacząco spadły. W znacznie większym stopniu jednak w przypadku Węgier niż Polski. W czeskim i słowackim sektorze przedsiębiorstw znaczące przyrosty zobowiązań z tytułu kredytów i pożyczek odnotowano w latach 1995 do 1997, odpowiednio 9,8\% PKB, 6,7\% PKB. W pozostałym okresie wartości te kształtowały się między $-0,8 \%$ PKB, a 2,5\% PKB (przedsiębiorstwa czeskie) oraz między $-0,7 \%$ PKB, a 2,9\% PKB (przedsiębiorstwa słowackie). W Czechach, na Węgrzech i w Polsce, 
w przeciwieństwie do Słowacji, znacznie większe przyrosty zobowiązań odnotowano z tytułu długoterminowych kredytów i pożyczek niż krótkoterminowych.

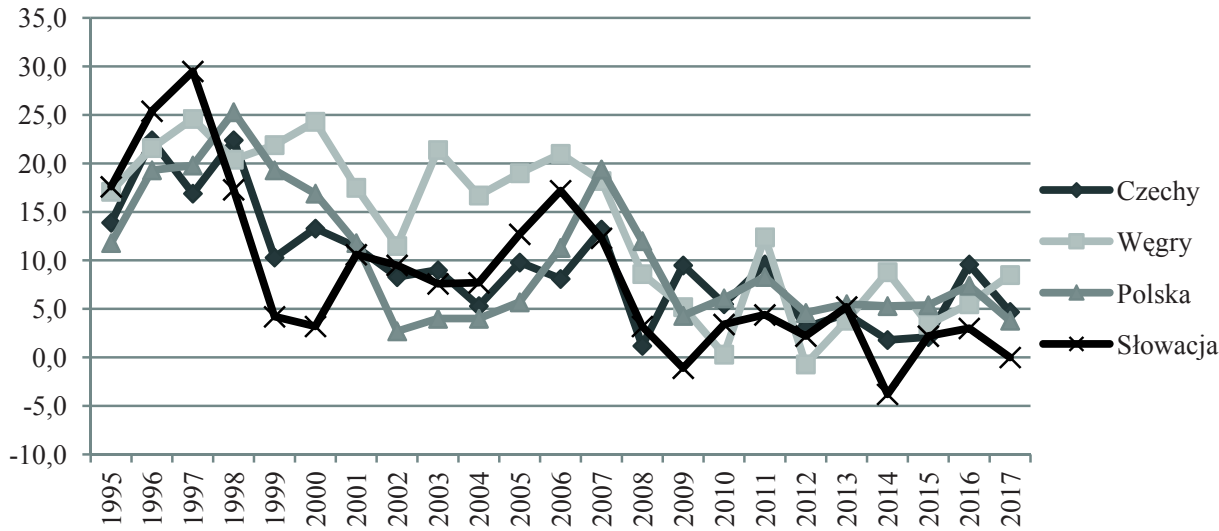

Rys. 2. Zaciągnięcie netto zobowiązań w przedsiębiorstwach niefinansowych w latach 1995-2017 (\% PKB, transakcje finansowe)

Fig. 2. Net incurrence of liabilities in non-financial corporations in the years 1995-2017 (\% of GDP, financial transactions)

Źródło: Eurostat: European sector accounts, https://ec.europa.eu/eurostat/web/sector-accounts/data/database (dostęp: 06.09.2018 r.).

W okresie 1995-2015 największe przyrosty z tytułu udziałów kapitałowych odnotowano w węgierskim sektorze przedsiębiorstw. Kształtowały się one między $0,6 \%$ PKB a 7,8\% PKB. W przedsiębiorstwach czeskich, polskich i słowackich znaczące przyrosty udziałów kapitałowych wystapiły w latach 1995 do 2009. W czeskim sektorze przedsiębiorstw wartości te kształtowały się w przedziale 2,8\% PKB do 5,3\% PKB, w polskim od 3,0\% PKB do 4,1\% PKB, w słowackim od 2,1\% PKB do 6,3\% PKB. Po roku 2009 wartości te znacząco obniżyły się. W przypadku udziałów kapitałowych podstawowym źródłem finansowania były akcje nienotowane na giełdach (przedsiębiorstwa czeskie, polskie i słowackie) oraz pozostałe udziały kapitałowe (przedsiębiorstwa węgierskie).

Kolejnym ważnym źródłem finansowania były pozostałe kwoty do otrzymania / zapłacenia. Kategoria ta jest bardzo szeroka i obejmuje swym zakresem kredyt handlowy i zaliczki oraz pozostałe kwoty nieobejmujące kredytów handlowych i zaliczek. „Kredyty handlowe i zaliczki to należności finansowe powstające $\mathrm{z}$ tytułu bezpośredniego udzielenia kredytu przez dostawców towarów i usług ich klientom oraz płatności zaliczkowych za prace niezakończone lub planowane, w formie przedpłaty dokonywanej przez klientów na poczet jeszcze niedostarczonych towarów lub niezrealizowanych usług." (Rozporządzenie Parlamentu Europejskiego i Rady (UE) NR 549/2013 z dnia 21 maja 2013 r., s. 186, 5.233). Pozostałe kwoty do otrzymania/zapłacenia nieobejmujące kredytów handlowych i zaliczek to „należności finansowe powstałe w wyniku różnic w czasie pomiędzy dokonywanymi transakcjami a płatnościami $\mathrm{z}$ tytułu, na przykład: [...] wynagrodzeń; [...] podatków i składek na ubezpieczenie społeczne [...].” (Rozporządzenie Parlamentu Europejskiego i Rady (UE) NR 549/2013 z dnia 21 maja 2013 r., s. 186, 5.241). We wszystkich analizowanych krajach, w latach 1995-2015, przyrosty zobowiązań z tytułu pozostałych 
kwot do otrzymania/zapłacenia utrzymywały się w trendzie spadkowych. W przypadku przedsiębiorstw czeskich wartości te ukształtowały się w przedziale 1,0\% PKB do $11,3 \%$ PKB, dla wegierskich od $0,6 \%$ PKB do 7,1\% PKB, dla polskich 1,4\% PKB do $10,9 \%$ PKB, dla słowackich od $-1,1 \%$ PKB do $8,5 \%$ PKB. Trend spadkowy dotyczy również wartości przyrostu kredytów handlowych i zaliczek.

Tabela 5. Przedsiębiorstwa niefinansowe - źródła finansowania (\% PKB, średnia okresu)

Table 5. Non-financial corporations - sources of financing ( $\%$ GDP, period average)

\begin{tabular}{|c|c|c|c|c|c|c|c|}
\hline Kraj & 1995-1997 & $1998-2000$ & $2001-2003$ & $2004-2006$ & $2007-2009$ & 2010-2012 & 2013-2015 \\
\hline & \multicolumn{7}{|c|}{ Dłużne papiery wartościowe } \\
\hline Czechy & 0,0 & 0,0 & $-0,8$ & $-0,5$ & 0,5 & 0,2 & 0,4 \\
\hline Węgry & 0,3 & $-0,1$ & 0,0 & 0,3 & 0,0 & 0,3 & $-0,2$ \\
\hline Polska & 0,2 & 0,9 & $-0,2$ & $-0,3$ & 0,2 & 0,9 & 0,9 \\
\hline \multirow[t]{2}{*}{ Słowacja } & 4,9 & 1,0 & $-0,1$ & 0,4 & $-0,1$ & 0,2 & 1,8 \\
\hline & \multicolumn{7}{|c|}{ Krótkoterminowe dłużne papiery wartościowe } \\
\hline Czechy & $-0,8$ & 0,0 & $-0,4$ & $-0,4$ & $-0,1$ & $-0,2$ & 0,0 \\
\hline Węgry & 0,0 & 0,0 & 0,0 & 0,0 & 0,0 & 0,0 & 0,0 \\
\hline Polska & 0,1 & 0,2 & 0,0 & $-0,1$ & 0,0 & 0,4 & $-0,3$ \\
\hline \multirow[t]{2}{*}{ Słowacja } & 3,5 & 1,2 & 0,0 & 0,0 & 0,2 & 0,2 & 0,0 \\
\hline & \multicolumn{7}{|c|}{ Długoterminowe dłużne papiery wartościowe } \\
\hline Czechy & 0,9 & $-0,1$ & $-0,4$ & $-0,1$ & 0,6 & 0,4 & 0,5 \\
\hline Węgry & 0,3 & 0,0 & 0,0 & 0,3 & 0,0 & 0,3 & $-0,2$ \\
\hline Polska & 0,1 & 0,7 & $-0,2$ & $-0,2$ & 0,2 & 0,6 & 1,2 \\
\hline \multirow[t]{2}{*}{ Słowacja } & 1,4 & $-0,3$ & $-0,1$ & 0,5 & $-0,2$ & $-0,1$ & 1,7 \\
\hline & \multicolumn{7}{|c|}{ Kredyty i pożyczki } \\
\hline Czechy & 9,8 & $-0,8$ & $-1,1$ & 2,5 & 2,0 & 1,7 & 1,7 \\
\hline Węgry & 6,3 & 7,4 & 8,3 & 9,7 & 9,1 & $-1,5$ & 1,3 \\
\hline Polska & 4,3 & 4,6 & 1,3 & 2,0 & 4,7 & 2,4 & 1,9 \\
\hline \multirow[t]{2}{*}{ Słowacja } & 6,7 & $-0,7$ & 2,9 & 0,8 & 2,9 & 0,8 & 1,3 \\
\hline & \multicolumn{7}{|c|}{ Krótkoterminowe kredyty i pożyczki } \\
\hline Czechy & 3,1 & $-0,8$ & $-0,9$ & 0,5 & 0,5 & 1,3 & 0,7 \\
\hline Węgry & 2,4 & 2,1 & 3,5 & 3,9 & 1,8 & 1,1 & $-0,2$ \\
\hline Polska & 1,5 & 1,4 & 0,2 & 0,4 & 0,7 & 1,1 & 0,3 \\
\hline \multirow[t]{2}{*}{ Słowacja } & 3,0 & 0,7 & 2,3 & 0,8 & 0,5 & 0,5 & 0,8 \\
\hline & \multicolumn{7}{|c|}{ Długoterminowe kredyty i pożyczki } \\
\hline Czechy & 6,8 & $-0,1$ & $-0,2$ & 2,0 & 1,4 & 0,4 & 1,0 \\
\hline Węgry & 3,8 & 5,2 & 4,7 & 5,9 & 7,4 & $-2,5$ & 1,4 \\
\hline Polska & 2,8 & 3,2 & 1,1 & 1,5 & 4,0 & 1,3 & 1,6 \\
\hline \multirow[t]{2}{*}{ Słowacja } & 3,6 & $-1,5$ & 0,5 & 0,0 & 2,4 & 0,3 & 0,5 \\
\hline & \multicolumn{7}{|c|}{ Udziały kapitałowe } \\
\hline Czechy & 4,7 & 4,9 & 5,3 & 3,4 & 2,8 & 0,7 & $-0,2$ \\
\hline Węgry & 7,5 & 7,8 & 5,9 & 4,5 & 0,6 & 5,6 & 4,1 \\
\hline Polska & 3,2 & 4,1 & 3,0 & 3,4 & 4,0 & 1,5 & 1,1 \\
\hline \multirow[t]{2}{*}{ Słowacja } & 4,1 & 3,0 & 3,6 & 6,3 & 2,1 & 0,9 & $-0,7$ \\
\hline & \multicolumn{7}{|c|}{ Akcje notowane } \\
\hline Czechy & & & 0,1 & 1,7 & 1,1 & 0,0 & 0,2 \\
\hline Węgry & 0,5 & 0,5 & 0,2 & $-0,1$ & $-0,2$ & 0,2 & 0,1 \\
\hline
\end{tabular}




\begin{tabular}{|c|c|c|c|c|c|c|c|}
\hline Polska & $-0,1$ & 1,6 & $-0,3$ & 1,1 & 1,5 & 0,5 & 0,3 \\
\hline Słowacja & $-0,1$ & 0,1 & 0,3 & 1,9 & 0,9 & 0,0 & 0,0 \\
\hline \multicolumn{8}{|c|}{ Akcje nienotowane } \\
\hline Czechy & 3,3 & 4,7 & 4,0 & 0,3 & 1,0 & $-0,2$ & 0,5 \\
\hline Węgry & 2,5 & 2,8 & 1,5 & 2,6 & $-0,7$ & 3,5 & 0,6 \\
\hline Polska & 3,3 & 2,5 & 2,2 & 0,6 & 1,6 & 0,7 & $-0,1$ \\
\hline Słowacja & 3,4 & 2,6 & 2,9 & 4,2 & 1,0 & 0,7 & $-0,7$ \\
\hline \multicolumn{8}{|c|}{ Pozostałe udziały kapitałowe } \\
\hline Czechy & 1,3 & $-0,4$ & 1,3 & 1,5 & 0,8 & 0,9 & $-0,9$ \\
\hline Węgry & 4,5 & 4,5 & 4,2 & 1,9 & 1,6 & 1,9 & 3,3 \\
\hline Polska & 0,0 & 0,0 & 1,1 & 1,6 & 0,9 & 0,3 & 0,9 \\
\hline Słowacja & 0,8 & 0,3 & 0,4 & 0,2 & 0,1 & 0,1 & $-0,1$ \\
\hline \multicolumn{8}{|c|}{ Instrumenty pochodne i opcje na akcje dla pracowników } \\
\hline Czechy & 0,0 & $-0,1$ & $-0,4$ & $-0,5$ & $-0,4$ & 0,1 & $-0,1$ \\
\hline Węgry & 0,0 & 0,0 & $-0,2$ & $-0,5$ & $-0,8$ & $-1,0$ & $-0,9$ \\
\hline Polska & 0,0 & 0,0 & 0,0 & 0,2 & 0,1 & 0,0 & 0,1 \\
\hline Słowacja & 0,0 & 0,0 & 0,0 & 0,0 & 0,0 & 0,0 & 0,0 \\
\hline \multicolumn{8}{|c|}{ Pozostałe kwoty do otrzymania / zapłacenia } \\
\hline Czechy & 3,2 & 11,3 & 6,5 & 2,8 & 3,2 & 3,4 & 1,0 \\
\hline Węgry & 7,0 & 7,1 & 2,9 & 5,0 & 1,7 & 0,6 & 1,1 \\
\hline Polska & 9,3 & 10,9 & 2,0 & 1,7 & 3,0 & 1,5 & 1,4 \\
\hline Słowacja & 8,5 & 4,9 & 2,9 & 5,1 & $-0,1$ & 1,4 & $-1,1$ \\
\hline \multicolumn{8}{|c|}{ Kredyty handlowe i zaliczki } \\
\hline Czechy & 1,1 & 7,9 & 3,7 & 0,9 & 2,9 & 2,1 & 0,4 \\
\hline Węgry & 4,6 & 5,7 & 1,8 & 3,5 & 1,1 & 0,6 & 0,6 \\
\hline Polska & 4,2 & 5,1 & 2,3 & 1,4 & 2,1 & 0,3 & 0,1 \\
\hline Słowacja & 3,3 & 1,1 & 0,9 & 3,6 & 0,6 & 1,0 & $-0,7$ \\
\hline
\end{tabular}

Źródło: Eurostat: European sector accounts, https://ec.europa.eu/eurostat/web/sector-accounts/data/database (dostęp: 06.09.2018 r.).

$\mathrm{Na}$ znacznie niższym poziomie niż $\mathrm{w}$ przypadku trzech analizowanych powyżej kategorii ukształtowały się przyrosty zobowiązań $\mathrm{z}$ tytułu dłużnych papierów wartościowych oraz instrumentów pochodnych. W przypadku dłużnych papierów wartościowych wartości przyrostów w analizowanych krajach nie przekraczały $1 \%$ PKB, przyjmując często wartości ujemne, bądź oscylujące wokół zera. Wyjątek stanowią jedynie przedsiębiorstwa słowackie z okresu 1995-1997, gdzie wartość przyrostów dłużnych papierów wartościowych przyjęła wielkość 4,9\% PKB oraz z lat 2013-2015, odpowiednio $1,8 \%$ PKB. W przypadku instrumentów pochodnych przyrosty przyjmowały wartości ujemne bądź też oscylowały wokół zera.

\section{Wnioski}

Na podstawie przeprowadzonych analiz dokonano następujących obserwacji:

- w latach 1995-2015 w przedsiębiorstwach czeskich, węgierskich, polskich i słowackich nastąił wzrost poziomu samofinansowania. Przyczyn tego wzrostu upatruje się, w przypadku przedsiębiorstw czeskich i słowackich, w wysokim poziomie oszczędności 
brutto, w przypadku natomiast przedsiębiorstw węgierskich i polskich, we wzroście poziomu oszczędności brutto, jak również w spadku wartości nakładów brutto na środki trwałe w sektorze przedsiębiorstw wszystkich analizowanych krajów,

- w okresie 1995-2017 wartość zaciagniętych netto zobowiązań w sektorze przedsiębiorstw Czech, Węgier, Polski i Słowacji ukształtowała się w trendzie spadkowym. Wśród przyczyn spadku zapotrzebowania na środki finansowe, pozyskiwane przez przedsiębiorstwa $\mathrm{z}$ innych sektorów instytucjonalnych, wskazano na wysoki poziom oszczędności brutto (Czechy, Słowacja), wzrost poziomu oszczędności brutto (Węgry, Polska), oraz spadek nakładów brutto na środki trwałe,

- w latach 1995-2015 podstawowym źródłem finansowania zewnętrznego były trzy kategorie instrumentów finansowych, a mianowicie: kredyty i pożyczki, udziały kapitałowe, pozostałe kwoty do otrzymania / zapłacenia. W analizowanym okresie pomimo spadku poziomu finansowania zewnętrznego nie nastąpiły znaczące zmiany w jego strukturze.

\section{Dyskusja}

$\mathrm{Na}$ gruncie literatury przyjęto, iż saldo wierzytelności i zadłużenia w sektorze przedsiębiorstw przyjmuje z reguły wartość ujemną. Oznacza to, iż sektor przedsiębiorstw staje się pożyczkobiorcą netto. Pożyczkodawcą netto są natomiast gospodarstwa domowe. W praktyce jednak saldo wierzytelności i zadłużenia w sektorze przedsiębiorstw często przyjmuje wartość dodatnią, jak to miało miejsce w sektorze przedsiębiorstw węgierskich, polskich czy słowackich (głównie po roku 2007). Wobec powyższego podejmowane są coraz częściej badania mające na celu wyjaśnienie tego zjawiska. Z przeglądu literatury dokonanego przez Cesaroni, De Bonis'a i Infante'a wynika, iż nie wypracowano, jak do tej pory, wspólnego stanowiska. I tak, dla czesści badaczy kluczowymi czynnikami stojącym za dodatnim saldem sektora przedsiębiorstw są: spadek poziomu inwestycji w przedsiębiorstwach, wzrost netto inwestycji zagranicznych, czy też wzrost zyskowności przedsiębiorstw, który związany jest z umiarkowanym wzrostem płac i niskimi stopami procentowymi. Inni przyczyn upatrują w konsekwencjach globalnego kryzysu finansowego, skłaniających przedsiębiorstwa do zwiększania oszczędności przy jednoczesnym obniżaniu inwestycji. Jeszcze inni wiążą analizowane zjawisko $\mathrm{z}$ trudnościami w pozyskiwaniu funduszy zewnętrznych, zwłaszcza kredytu bankowego. Część badaczy dodatnie saldo sektora przedsiębiorstw wiąże ze spadkiem konsumpcji, która wpływa na poziom inwestycji oraz ze zjawiskiem deindustrializacji w krajach bogatych będącym efektem globalizacji (Cesaroni, De Bonis, Infante, 2016, s. 2-4). Pojawia się więc pytanie, czy oprócz kategorii ekonomicznych, które były przedmiotem analiz, również inne wpłynęły na kształt salda wierzytelności i zadłużenia w sektorze przedsiębiorstw czeskich, węgierskich, polskich i słowackich. Trudno jednak bez pogłębionych badań jednoznacznie odpowiedzieć na tak postawione pytanie. Na gruncie literatury zwraca się bowiem uwagę na bardzo szerokie spektrum różnych czynników mających wpływ na kształt owego salda. Warto więc $\mathrm{w}$ przyszłości podjąć pogłębione badania w tym zakresie.

$\mathrm{Na}$ gruncie literatury prowadzone są również badania dotyczące zmian w finansowaniu przedsiębiorstw. Z analiz prowadzonych przez Niemiecki Bank Federalny wynika, iż w ostatniej dekadzie dokonały się znaczące zmiany w strukturze finansowania przedsiębiorstw niefinansowych strefy euro (głównie: niemieckich, francuskich, włoskich i hiszpańskich). Zwrócono uwagę na trzy podstawowe trendy: 
- nastąpiło przesunięcie akcentu ze środków pochodzących z zewnątrz (finansowanie zewnętrzne) na wykorzystanie nadwyżek generowanych przez przedsiębiorstwa (finansowanie wewnętrzne),

- w strukturze finansowania zewnętrznego zaobserwowano tendencję przechodzenia z kapitału obcego na kapitał własny,

- w ramach finansowania dłużnego straciły na znaczeniu kredyty bankowe na rzecz innych form długu, takich jak pożyczki od podmiotów niebędących bankami, czy dłużne papiery wartościowe (Deutsche Bundesbank, 2018, s. 54).

Pierwszą obserwację potwierdzają także doświadczenia przedsiębiorstw niefinansowych czeskich, węgierskich, polskich, czy słowackich. Drugiej obserwacji natomiast potwierdzić nie można $\mathrm{w}$ analizowanych krajach. Nie zaobserwowano istotnych zmian w strukturze finansowania zewnętrznego w sektorze przedsiębiorstw Czech, Węgier, Polski, Słowacji. Co do trzeciej konkluzji trzeba zauważyć, iż z analizowanej w badaniach kategorii „kredyty i pożyczki” nie wyodrębniono kredytu bankowego. Stąd też nie można do trzeciej obserwacji odnieść sytuacji przedsiębiorstw w analizowanych krajach. Warto byłoby jednak podjąc badania mające na celu określenie roli finansowania bankowego w gospodarce finansowej współczesnego przedsiębiorstwa.

\section{Bibliografia}

Cesaroni, T., De Bonis, R., Infante, L. (2016). On the determinants of firms' financial surpluses and deficits, /w/ IFC Bulletin No 43, Statistical implications of the new financial landscape, Proceedings of the Eighth IFC Conference, Basel, 8-9 September 2016 March. Pobrano 18.09.2018 z: https://www.bis.org/ifc/ publ/ifcb43.pdf

Deutsche Bundesbank, Developments in corporate financing in the euro area since the financial and economic crisis. Monthly Report, January 2018. Pobrano 24.09.2018 z: https://www.bundesbank.de/Redaktion/EN/ Downloads/Publications/Monthly_Report_Articles/2018/2018_01_developemtents.pdf?_blob=publication File.

Eurostat: European sector accounts. Pobrano 6.09.2018 z: https://ec.europa.eu/eurostat/web/sector-accounts/ data/database

GUS (Główny Urząd Statystyczny) (2000). Zeszyty metodyczne i klasyfikacje. Europejski system rachunków narodowych i regionalnych ESA 1995. Departament Rachunków Narodowych i Finansów, GUS, Warszawa, sierpień 2000

GUS (Główny Urząd Statystyczny) (1996). Zeszyty metodyczne. System rachunków narodowych (SRN). Tom 1. GUS, Warszawa, luty 1996

GUS (Główny Urząd Statystyczny) (1997). Zeszyty metodyczne. System rachunków narodowych (SRN). Tom II GUS, Warszawa, listopad 1997.

ROZPORZA¿DZENIE PARLAMENTU EUROPEJSKIEGO I RADY (UE) NR 549/2013 z dnia 21 maja 2013 r. w sprawie europejskiego systemu rachunków narodowych i regionalnych w Unii Europejskiej, Dziennik Urzędowy Unii Europejskiej L 174/1.

United Nations, NATIONAL ACCOUNTS: A PRACTICAL INTRODUCTION, Studies in Methods Series F, No.85, Handbook of National Accounting, Department of Economic and Social Affairs Statistics Division, New York, 2003.

For citation:

Samborski A. (2019). Finansowanie przedsiębiorstw w krajach Grupy Wyszehradzkiej. Problemy Rolnictwa Światowego, 19(1), 98-109; DOI: 10.22630/PRS.2019.19.1.9

Samborski A. (2019). Financing Enterprises in the Visegrad Group Countries (in Polish). Problems of World Agriculture, 19(1), 98-109; DOI: 10.22630/PRS.2019.19.1.9 